\title{
Direct and indirect influences of intercrops on the coconut defoliator Opisina arenosella
}

\author{
K. S. Shameer ${ }^{1}$ M. Nasser ${ }^{1} \cdot{\text { Chandrika } \text { Mohan }^{2} \cdot \operatorname{Ian} \text { C. W. Hardy }}^{3}$
}

Received: 5 March 2017/Revised: 9 July 2017/ Accepted: 24 July 2017/Published online: 9 August 2017

(C) The Author(s) 2017. This article is an open access publication

\begin{abstract}
Coconut palm (Cocos nucifera) infestation by Opisina arenosella (Lepidoptera: Oecophoridae) in the Indian subcontinent may occur in November to May each year in the same or adjoining areas of plantations. Parasitoids of $O$. arenosella may also be consistently present at these times. During other periods, pests and/or parasitoids could be maintained on intercrops that are commonly grown throughout the year. Field surveys of 54 intercrop species in Kerala, India, found that $O$. arenosella attacks banana, but not others, while laboratory screening showed that $O$. arenosella can mature on jack fruit, cashew and oil palm. Larvae of 20 lepidopteran species found on intercrops were screened for use by Goniozus nephantidis (Hymenoptera: Bethylidae), a larval parasitoid of $O$. arenosella, which oviposited on two species but its offspring failed to mature. Thirteen intercrop herbivore species were screened for use by Brachymeria nosatoi (Hymenoptera: Chalcididae), a pupal parasitoid of $O$. arenosella, which completed development on the pyralids Herculia nigrivita, Syllepte derogata and Psara basalis. Further, connectance trophic webs were compiled using prior field records of coconut, 33 species of intercrops, 58 species of lepidopteran
\end{abstract}

Communicated by V. Gagic.

Ian C. W. Hardy

ian.hardy@nottingham.ac.uk

1 Insect Ecology and Ethology Laboratory, Department of Zoology, University of Calicut, Calicut University P.O., Malappuram, Kerala 673635, India

2 Department of Entomology, ICAR - Central Plantation Crops Research Institute, Regional Station, Kayamkulam, Kerala 690533, India

3 School of Biosciences, University of Nottingham, Sutton Bonington Campus, Loughborough,

Leicestershire LE12 5RD, UK herbivores and 29 species of primary parasitoids. Both laboratory and literature evidence suggests that populations of $O$. arenosella are unlikely to be maintained by feeding on intercrops or strongly influenced by direct competition with other lepidopterans but are likely to be affected by sharing parasitoids. Intercrop herbivores have clear potential for maintaining parasitoids of $O$. arenosella, and we recommend thirteen plant species as intercrops that should aid in conservation biocontrol.

Keywords Plant-herbivore-parasitoid associations . Trophic connectance webs - Apparent competition . Natural enemy maintenance $\cdot$ Coconut intercrops

\section{Key message}

- Intercrop plants may harbour pests and their natural enemies. The pros and cons of intercropping are likely to vary across agro-ecosystems.

- In coconut plantations, intercrops are little utilized by the major pest of coconut, nor do intercrop herbivores substantially attack coconut. Direct ecological interactions are thus likely to be weak.

- There is a considerable degree of shared parasitism between coconut and intercrop herbivores. Pest populations could thus be suppressed by indirect interactions. Intercrop species are recommended to promote such effects.

\section{Introduction}

The coconut palm, Cocos nucifera $\mathrm{L}$., is grown in more than 93 countries, in areas totalling 12,479 million $\mathrm{Ha}$, and yields harvest in all seasons. It is regarded in tropical 
countries as the 'Tree of Life' (Foale 2003). In India, the coconut cultivation industry directly or indirectly employs approximately 12 million people and contributes 1.28 billion USD to GDP (Thomas 2013). Coconut is, however, attacked by more than 800 species of pests. In India and Sri Lanka, one of the major pests is the coconut leaf eating caterpillar Opisina arenosella Walker (Lepidoptera: Oecophoridae), with outbreaks causing serious damage to coconut and other palms, typically via feeding on the underside of leaves whilst protected by a gallery made of frass and silken threads (Nirula 1956; Mohan and Sujatha 2006; Singh and Rethinam 2006; Kumara et al. 2015; Fig. 1.). For instance, Mohan et al. (2010) reported that the nut yield of infested coconut palms could be reduced by as much as $45.4 \%$ in the year following severe pest incidence and also that the number of flower bunches and leaves could be reduced by 21 and $13.8 \%$, respectively. Opisina arenosella is also reported to infest a number of other species of palms (palmyra palm, Borassus flabellifer Linn.,
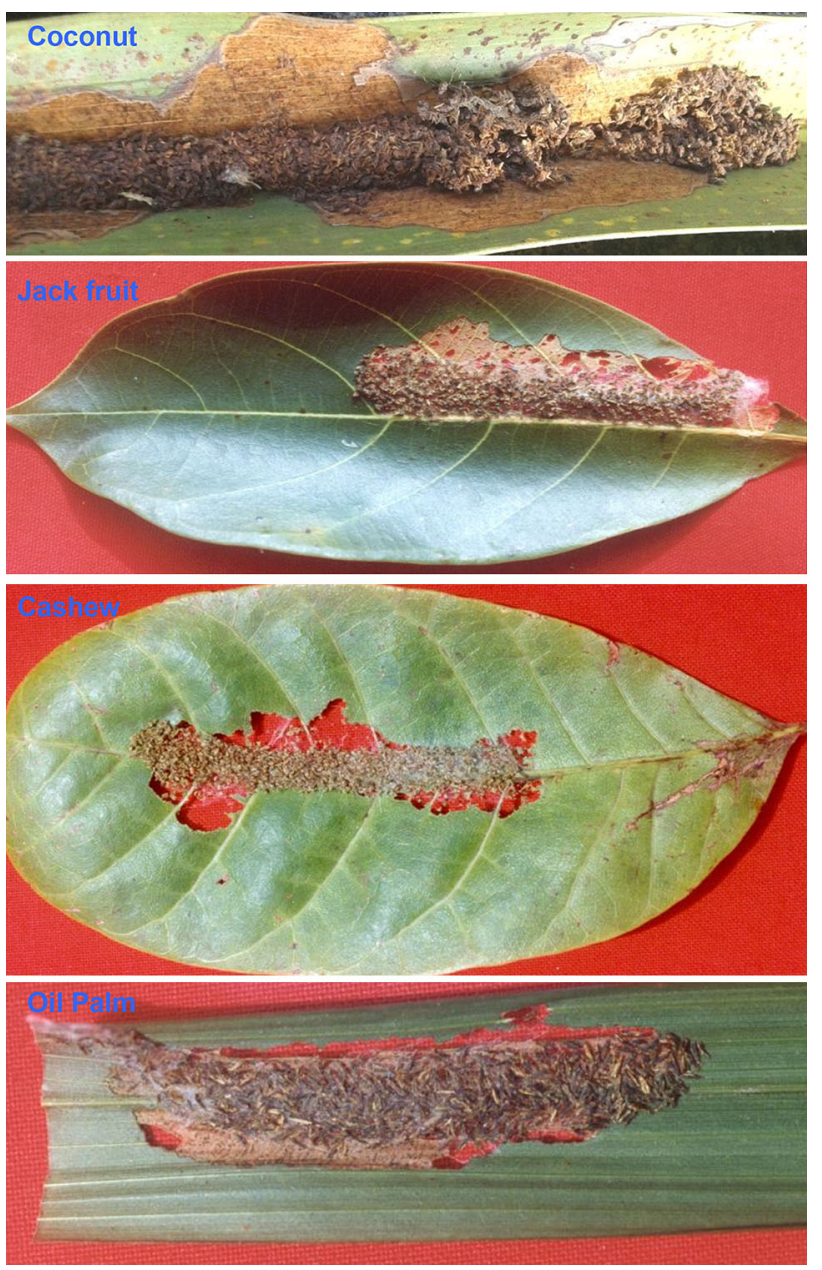

Fig. 1 Characteristic feeding galleries made by individual $O$. arenosella larvae on coconut (upper panel) and on the leaves of different intercrop plants
Rao et al. 1948; Murthy et al. 1995; date palm, Phoenix dactylifera Linn., Butani 1975; Talati and Kapadia 1984; fan palm, Livistona chinensis, wild date palm, Phoenix sylvestris, Talati and Kapadia 1984; talipot palm, Corypha umbraculifera Linn., Talati and Kapadia 1984; Sadakathulla et al. 1999).

Opisina arenosella occurrence varies seasonally, with both high temperatures and high humidity reported to favour the build-up of populations on coconut palms (Sathiamma et al. 1973; Narendran et al. 1978; Nadarajan and Channabasavanna 1980). In south India, oviposition is most common from November to March and the highest abundance of early instar larvae is observed during November to December (Nadarajan and Channabasavanna 1980) but overall the largest numbers of $O$. arenosella may be observed between February and May (Narendran et al. 1978).

There is relatively little known about the abundance and activity of $O$. arenosella during the period in which coconut palm is not typically infested (June to October). One possibility is that the pest population is maintained by utilizing non-palm plant species. In other cropping systems, alternative host plants can support pests during periods when primary hosts are seasonally unavailable, and subsequently these pests migrate back to the primary host plants (Clementine et al. 2005; Goodell 2009; Saeed et al. 2015) and the availability, density and type of alternative host plants can be important factors influencing the damage caused by insect pests (Power 1987; Settle et al. 1996; Atakan and Uygur 2005; van Veen et al. 2006a; Zhang et al. 2017; but see Feng et al. 2017). Such alternative host plants are potentially present in the coconut agro-ecosystem because a wide variety of intercrop species are commonly grown within plantations and at all times of the year. The height of the coconut palms and the orientation of leaves allow $20-50 \%$ of sunlight transmission to reach the ground, making it possible for many annual and perennial plants to be grown in the spaces between coconut trunks (Nelliat et al. 1974), ideally without incurring substantial yield loss in the main crop (Letourneau et al. 2011; Iverson et al. 2014). The common intercrops recommended to be grown with coconut include banana, cocoa, pineapple, tuber crops (tapioca, colocasia, yam), spices (clove, black pepper, nutmeg, ginger) and vegetables (Balasundaram and Aiyadurai 1963; Varghese et al. 1978; Bavappa et al. 1986; Hegde et al. 1993). It is already known that $O$. arenosella is able to infest banana plants (Musa paradisiaca L.) (Talati and Butani 1988; Manjunath 1985), but there is little information on whether the remaining intercrop plants can act as alternative hosts and thus support populations of this pest.

Opisina arenosella is attacked by a number of species of indigenous natural enemies, including parasitoids. The 
early larval parasitoid, Apanteles taragammae Viereck (Hymenoptera: Braconidae), the late-larval parasitoid Goniozus nephantidis (Muesebeck) (Hymenoptera: Bethylidae), the pre-pupal parasitoid Elasmus nephantidis Rohwer (Hymenoptera: Elasmidae) and the pupal parasitoid Brachymeria nosatoi Habu (Hymenoptera: Chalcididae) are all typically found in coconut plantations in Kerala during the $O$. arenosella infestation period, i.e. November to May, each year (S.K.S. pers. obs.). These are considered to be the most important natural enemies of $O$. arenosella. The release of $G$. nephantidis, E. nephantidis and B. nosatoi at fixed rates and intervals can result in a significant pest population reduction (Sathiamma et al. 1987, 1996). Estimates of parasitism rates range from 4.23 to $59.50 \%$ for $A$. taragamae, $19.57 \%$ for $G$. nephantidis and $41.6 \%$ for Brachymeria spp. (chiefly B. nosatoi) (Mohamed et al. 1982; Mohan and Sujatha 2006). Although many predators of $O$. arenosella, such as mites, ants, spiders, anthocorid bugs, are reported, none of these exhibit host attack rates or achieve the same population suppression as the parasitoids.

As with $O$. arenosella, there is relatively little known about the activity of natural enemies during June to October but it is possible that parasitoid populations are maintained by reproduction on pests that infest the intercrop plant species in coconut plantations. To date, the laboratory evaluations of the suitability of different lepidopteran species as hosts for mass-rearing parasitoids of $O$. arenosella have shown that both $G$. nephantidis and $B$. nosatoi can be reared on some alternative host species (Dharmaraju 1952; Mohamed et al. 1982, 1983; Remadevi et al. 1996; Shameer and Mohan 2002; Mohan and Shameer 2003). As with other cropping systems (Settle et al. 1996; Valladares and Salvo 1999; Goodell 2009; Koji et al. 2012; Saeed et al. 2015), reproduction of natural enemies on alternative hosts, themselves feeding on alternative host plants, could influence the suppression of $O$. arenosella damage to coconut production.

Here, we evaluate the possibility that $O$. arenosella populations utilize intercrop plants and, similarly, the possibility that populations of its natural enemies also attack alternative hosts which are found on these intercrop plants. We do this by directly surveying intercrop plants present within the coconut cropping system and testing the ability of $O$. arenosella to feed and develop on these plant species. We also test the ability of some common parasitoids of $O$. arenosella to develop on lepidopteran herbivores of intercrops. Additionally, we construct, from prior literature, connectance trophic webs (Memmott and Godfray 1994) of the coconut agro-ecosystem: such trophic networks record the presence and absence of trophic interactions between coconut and intercrop plants and their herbivores and between these herbivores and their parasitoids. We use these heuristically to further infer the host- plant range of the herbivores, the host range of the parasitoids and the importance of direct (e.g. competition) and indirect (e.g. apparent competition) interactions on $O$. arenosella populations. We conclude by recommending intercrop species to be grown within the coconut agroecosystem to promote the conservation biocontrol of $O$. arenosella.

\section{Materials and methods}

\section{Field survey of intercrop plants}

Field observations were conducted in four geographically similar locations within Kerala twice each year, during the pest infestation (November to May) and non-infestation periods (June to October), for 2 years (2010-11 and 2011-12). These locations were spread approximately evenly over a $\sim 200 \mathrm{~km}$ distance, from north to south: Cochin, Aleppey, Kayangulam and Trivandrum (Fig. 2). The maximum temperature of these locations was $32-34{ }^{\circ} \mathrm{C}$ (means for each location were 29, 29, 28 and $27{ }^{\circ} \mathrm{C}$, respectively) and the average relative humidity was 84-90\%, with annual rainfall of 1700-2700 mm (Meteorological Centre, Trivandrum, http://www.imdtvm.gov.in/).

In each period and at each location, all the available intercrops grown in coconut plantations and other commonly cultivated crops, including ornamental plants, in coconut plantations and nearby areas (those immediately abutting the plantations, typically fields of rice) were surveyed. A minimum of five coconut plantations in which intercrops were abundant were surveyed in each location. In total, 54 intercrop species were found and at least 50 plants of each species were observed (Table 1). The incidence of $O$. arenosella on these plant species and also the presence of other species of lepidopteran larvae were recorded.

Leaf material from all the observed plant species was collected and used in subsequent laboratory evaluation of $O$. arenosella performance (see below). Similarly, lepidopteran larvae feeding on these plant species were collected for laboratory evaluations of parasitoid host range (see below). All subsequent laboratory work was conducted between 27 and $33^{\circ} \mathrm{C}$ and 65 and $77 \%$ relative humidity.

\section{Screening of intercrop feeding by $\boldsymbol{O}$. arenosella larvae}

Leaves of all the intercrop species observed in the field were brought to the laboratory and screened for feeding by $O$. arenosella larvae. There were ten replicates for each intercrop plant species plus 10 replicates using coconut leaves. Leaves were selected haphazardly from plants of each 


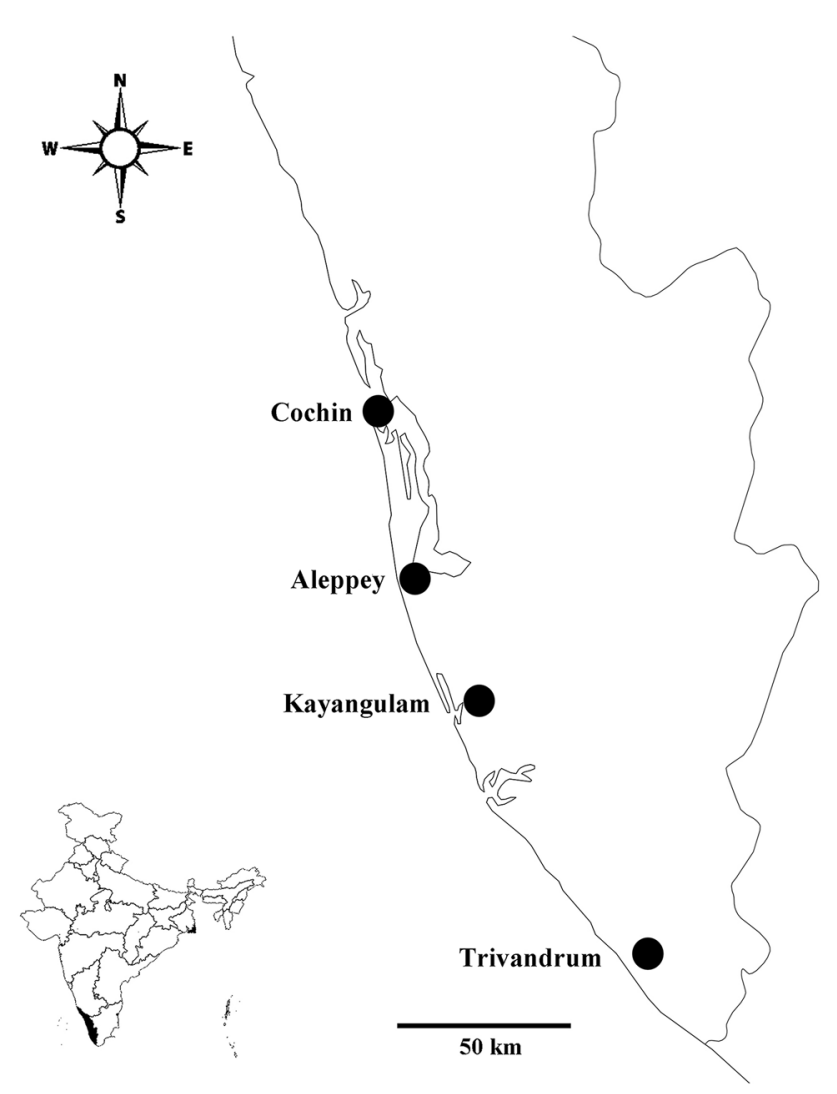

Fig. 2 Locations of field sites within Kerala Cochin (Kochi): $09^{\circ} 57^{\prime} \mathrm{N}$ Latitude, $76^{\circ} 16^{\prime} \mathrm{E}$ Longitude. Aleppey (Alappuzha): $9^{\circ} 5^{\prime} \mathrm{N}$ Latitude, $76^{\circ} 33^{\prime} \mathrm{E}$ Longitude. Kayangulam (Kayamkulam): $9^{\circ} 8^{\prime} \mathrm{N}$ Latitude, $76^{\circ} 30^{\prime} \mathrm{E}$ Longitude. Trivandrum (Thiruvananthapuram) $\left(08^{\circ} 29^{\prime} \mathrm{N}\right.$ Latitude, $76^{\circ} 57^{\prime} \mathrm{E}$ Longitude). Inset: Map of India showing Kerala in the south west. (Map constructed using SimpleMappr, Shorthouse 2010)

species, using the same variety of plant within a species. In each replicate, a fresh leaf of uniform size within each species was presented to a single 3-week-old larva in a glass beaker $(12 \mathrm{~cm} \times 9 \mathrm{~cm}$, Merck). Each leaf was checked for signs of feeding by $O$. arenosella larvae at 24 -h intervals and replaced with a fresh leaf for five continuous days. When feeding was observed, the fed portions on the leaf were measured (using a Leica S8 APO Stereozoom trinocular microscope equipped with Leica Application Suite Version $4.2)$ to assess the area consumed by the larvae. The average daily rate of feeding by the larva was then calculated in terms of $\mathrm{cm}^{2}$ of leaf eaten per day. Data on feeding rates had nonconstant variance across plant species (Bartlett's test on residuals from Analysis of Variance [ANOVA] of feeding rate across plant species: $\chi^{2}=361.64, \mathrm{df}=24, P<0.001$ ) and were not normally distributed (Shapiro-Wilk test on residuals: $W=0.843, P<0.001$ ) so the effects of plant species on feeding rate were analysed using a nonparametric Kruskal-Wallis test (Siegel and Castellan 1988) in the GenStat statistical package (v.17.1, VSN International Ltd., Hemel Hempsted, UK).

\section{Performance of $\boldsymbol{O}$. arenosella feeding on intercrop plants}

Studies on the survival and development of $O$. arenosella were conducted using the three host plants on which comparatively high feeding rates were observed (Fig. 3): Artocarpus heterophyllus (Jack fruit), Elaeis guineensis (Oil palm) and Anacardium occidentale (Cashew), plus coconut palm leaves (C. nucifera). In each replicate a freshly hatched first instar $O$. arenosella larva was transferred onto the leaf in a glass beaker, as above, and reared on them. Fresh leaves were provided every $48 \mathrm{~h}$ until pupation of $O$. arenosella larvae. Great care was taken during the transfer of early instar larvae onto fresh leaves; those which were injured or lethargic were excluded from the experiment, as were replicates in which the larva died. The larval period, pupal period and the longevity of the successfully developing adult female moths were recorded. For each plant species, there were ten replicates yielding adult moths. Data on the length of $O$. arenosella developmental stages and adult longevity had homogenous variance (Bartlett's test on residuals from ANOVA of developmental time across plant species: Larval period, $\chi^{2}=5.13$, df $=3, P=0.163 ;$ Pupal period, $\chi^{2}=0.15$, $\mathrm{df}=3, \quad P=0.986 ; \quad$ Longevity, $\quad \chi^{2}=1.58, \quad \mathrm{df}=3$, $P=0.664$ ) and were normally distributed (Shapiro-Wilk test: Larval period, $W=0.978, P=0.632$; Pupal period, $W=0.981, \quad P=0.714 ; \quad$ Longevity, $\quad W=0.974$, $P=0.472$ ). Thus, the effects of plant species on each of these measures were tested using one-way ANOVA in GenStat. Aggregation of factor levels was used to evaluate differences between treatments when overall results were significant (Crawley 1993). Once the minimal adequate (parsimonious) model was found, plots of the residuals against the fitted values, the standard normal distribution and plant species were used to check the assumptions of homogeneity of variance, normality and independence, respectively (Crawley 1993).

\section{Screening of intercrop herbivores as alternative hosts for parasitoids of $\boldsymbol{O}$. arenosella}

\section{Goniozus nephantidis}

Screening was carried out on 20 species of lepidopterans, belonging to six families, which were found on intercrop species (Table 2). Potential hosts were selected based on the size of the larvae being similar to those of $O$. arenosella. All larvae were collected from their respective intercrop host plants in the field and subsequently maintained in the laboratory on the leaves of these host plants until they developed to the size of a late-instar $O$. arenosella larva. The late-instar caterpillars were placed 
Table 1 Intercrop plants surveyed in the field*

\begin{tabular}{|c|c|c|c|c|}
\hline Family & Species & Common name & Host type & Type of plant \\
\hline Amaranthaceae & Amaranthus viridis $\mathrm{L}$. & Slender amaranth & Vegetable & Herb \\
\hline \multirow[t]{2}{*}{ Anacardiaceae } & Anacardium occidentale L. & Cashew apple, Cashew-nut tree & Crop & Tree \\
\hline & Mangifera indica $\mathrm{L}$. & Mango tree & Fruit & Tree \\
\hline Annonaceae & Annona squamosa $\mathrm{L}$. & Custard apple & Fruit & Tree \\
\hline \multirow[t]{2}{*}{ Araceae } & $\begin{array}{l}\text { Amorphophalus paeonifolius (Dennst.) } \\
\text { Nicolson }\end{array}$ & Elephant foot yam & $\begin{array}{l}\text { Vegetable/tuber } \\
\text { crop }\end{array}$ & Herb \\
\hline & Colocasia esculenta (L.) Schott. & Taro, Wild taro & $\begin{array}{l}\text { Vegetable/tuber } \\
\text { crop }\end{array}$ & Herb \\
\hline \multirow[t]{2}{*}{ Arecaceae } & Areca catechu $\mathrm{L}$. & Areca palm, Betel nut palm & Crop & Tree \\
\hline & Elaeis guineensis Jacq. & Oil palm & Crop & Tree \\
\hline Bromeliaceae & Ananas comosus (L.) Merr. & Pineapple & Fruit & Herb \\
\hline Caricaceae & Carica papaya $\mathrm{L}$. & Papaya & Fruit & Shrub \\
\hline Combretaceae & Terminalia catappa $\mathrm{L}$. & Indian almond tree & Crop & Tree \\
\hline Convolvulaceae & Ipomoea batatas (L.) Lam. & Sweet potato & Tuber crop & Climber \\
\hline \multirow[t]{5}{*}{ Cucurbitaceae } & Coccinia indica Wight \& Arn. & Little gourd, Ivy gourd & Vegetable & Climber \\
\hline & Cucumis sativus L. & Cucumber & Vegetable & Climber \\
\hline & Cucurbita moschata (Duchesne ex Lam.) & Pumpkin & Vegetable & Climber \\
\hline & Momordiaca charantia L. & Bitter gourd & Vegetable & Climber \\
\hline & Trichosanthes anguina $\mathrm{L}$. & Snake gourd & Vegetable & Climber \\
\hline Dioscoriaceae & Dioscorea alata $\mathrm{L}$. & Yam, Greater yam & $\begin{array}{l}\text { Vegetable/tuber } \\
\text { crop }\end{array}$ & Climber \\
\hline \multirow[t]{2}{*}{ Euphorbiaceae } & Manihot esculenta Crantz. & Cassava & Tuber crop & Shrub \\
\hline & Ricinus communis $\mathrm{L}$. & Castor oil plant & Crop & Shrub \\
\hline \multirow[t]{5}{*}{ Fabaceae } & Acacia mangium Willd. & Manjium & Timber crop & Tree \\
\hline & Arachis hypogea $\mathrm{L}$. & Groundnut, Peanut & Pulse & Herb \\
\hline & Cassia fistula $\mathrm{L}$. & Cassia & Ornamental & Tree \\
\hline & Gliricidia maculata (Steud.) & Gliricidia, Quickstick & Weed & Tree \\
\hline & Vigna unguiculata (L.) Walp. & Cowpea & Vegetable & Climber \\
\hline \multirow[t]{2}{*}{ Graminae } & Oryza sativa $\mathrm{L}$. & Rice & Cereal & Herb \\
\hline & Saccharum officinarum $\mathrm{L}$. & Sugarcane & Crop & $\begin{array}{l}\text { Perennial } \\
\text { Herb }\end{array}$ \\
\hline Guttiferae & Garcinia mangostana L. & Mangostein & Fruit & Tree \\
\hline Labiatae & Ocimum sanctum $\mathrm{L}$. & Thulasi, Sacred basil & Medicinal & Shrub \\
\hline Lauraceae & Cinnamomum zeylanicum Blume & Cinnamon & Spice & Tree \\
\hline \multirow[t]{2}{*}{ Malvaceae } & Abelmoschus esculentus (L.) Moench & $\begin{array}{l}\text { Bhindi, Okra, Ladies' fingers, } \\
\text { Gumbo }\end{array}$ & Vegetable & Herb \\
\hline & Hibiscus rosa-sinensis $\mathrm{L}$. & Shoe flower & Ornamental & Shrub \\
\hline Marantaceae & Maranta arundinacea $\mathrm{L}$. & Arrow root & Tuber crop & Herb \\
\hline \multirow[t]{4}{*}{ Moraceae } & Artocarpus heterophyllus Lam. & Jack fruit tree & Fruit & Tree \\
\hline & Artocarpus hirsuitus Lam. & Wild Jack & Fruit & Tree \\
\hline & Ficus religiosa $\mathrm{L}$. & Sacred fig, Peepal tree & Fruit & Tree \\
\hline & Morus albaL. & Mulberry & Fruit & Shrub \\
\hline Musaceae & Musa paradisiaca $\mathrm{L}$. & Banana & Fruit & Herb \\
\hline Myristicaceae & Myristica fragrans Houtt. & Nutmeg tree & Spice & Tree \\
\hline \multirow[t]{2}{*}{ Myrtaceae } & Syzygium aromaticum (L.) Merr. \& Perry & Clove tree & Spice & Tree \\
\hline & Psidium guajava $\mathrm{L}$. & Guava & Fruit & Tree \\
\hline Orchidaceae & Vanilla planifolia Andr. & Vanila & Spice & Climber \\
\hline Piperaceae & Piper nigrum $\mathrm{L}$. & Pepper, Black pepper & Spice & Climber \\
\hline \multirow[t]{2}{*}{ Rubiaceae } & Coffea arabica $\mathrm{L}$. & Coffee, Arabian coffee & Crop & Shrub \\
\hline & Ixora javanica (Blume) DC. & Asoka thechi, Jungle Geranium & Ornamental & Shrub \\
\hline
\end{tabular}


Table 1 continued

\begin{tabular}{lllll}
\hline Family & Species & Common name & Host type & Type of plant \\
\hline Rutaceae & Citrus $\times$ aurantifolia (Chistm. \& Panz.) & Key lime & Fruit & Shrub \\
& Swingle & & Timber crop & Tree \\
Simaroubaceae & Ailanthus excelsa Roxb. & Tree of Heaven & Vegetable & Herb \\
Solanaceae & Capsicum annuum L. & Chilli & Vegetable & Herb \\
& Lycopersicum esculentum Mill. & Tomato & Vegetable & Shrub \\
Sterculiaceae & Solanum melongena L. & Brinjal, Eggplant, Aubergine & Crop & Tree \\
Verbenaceae & Tectona grandis L. & Cocco, Cacao & Timber crop & Tree \\
Zingiberaceae & Cucurma longa L. & Teak, Indian-oak & Spice & Herb \\
& Zingiber officinale Rosc. & Ginger & Spice & Herb
\end{tabular}

* At least 50 plants of each species were observed. Opisina arenosella was found only on banana (Musa paradisiaca L.)

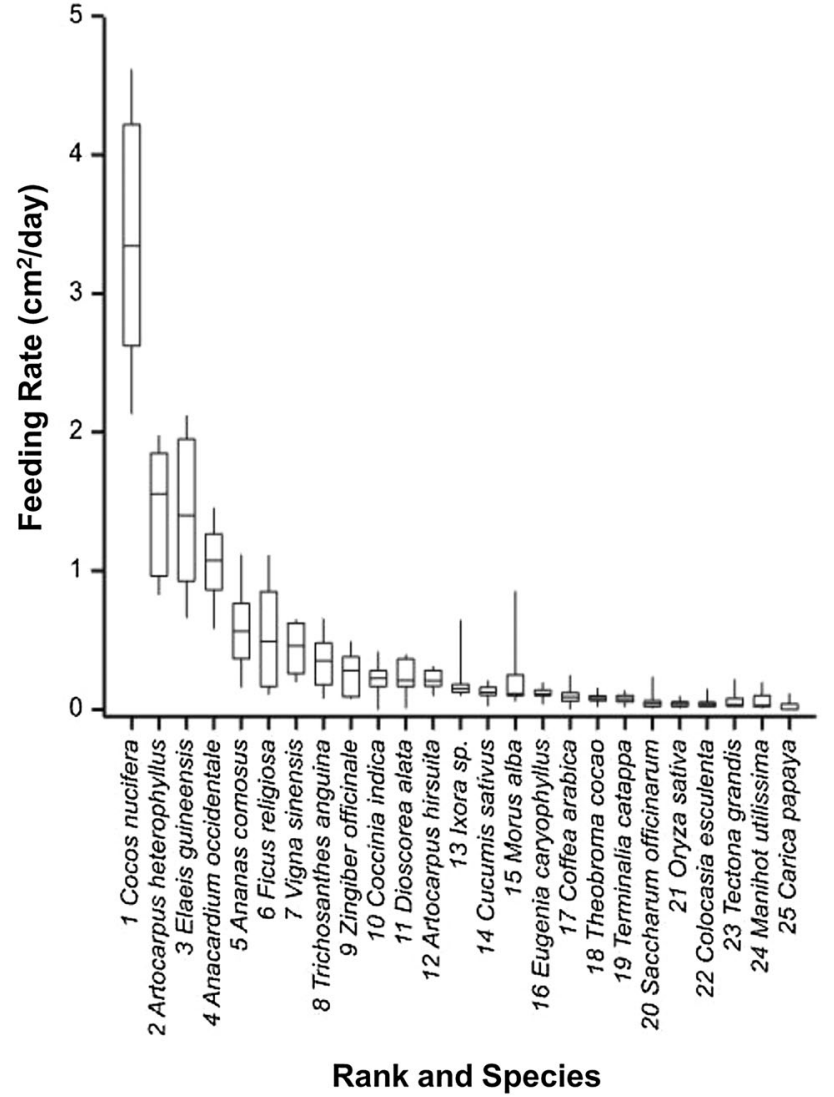

Fig. 3 Feeding activity of $O$. arenosella larvae on coconut (Cocos nucifera) leaves and on leaves of 24 species of intercrops. Species are shown ranked according to median rate of feeding. Other species of intercrops tested were not fed on at all. Bars within boxes indicate medians, ends of boxes indicate upper and lower quartiles and whiskers indicate variability and skew

individually in glass tubes $(10.5 \times 2.5 \mathrm{~cm}$, Borosil $)$ containing a 5-day-old mated female G. nephantidis. The tubes were inspected daily under a stereomicroscope and any evidence of attack, oviposition and parasitoid development was recorded. Given a suitable host, G. nephantidis females normally sting and paralyze the larva on the day of exposure, typically lay eggs within $24 \mathrm{~h}$ and any eggs normally hatch around 1 day after being laid (S.K.S. \& I.C.W.H. pers. obs.). To determine whether hosts were attacked, eggs were laid and if any hatched eggs developed as larvae, we observed each tube for 5 days. There were ten replicates for each of the 20 lepidopteran species.

\section{Brachymeria nosatoi}

Screening for use as hosts by $B$. nosatoi Habu was carried out on 13 species of Lepidoptera, belonging to five families, which were found on intercrop species (Table 2). Potential hosts were selected on the basis of having similar size to $O$. arenosella. Potential hosts were collected in the larval stage from infested plants in the field, and reared on leaves of their respective host plants until they pupated. Since the naked (without silken cocoon) pupae of $O$. arenosella are readily accepted for oviposition by $B$. nosato $i$ females in the laboratory (S.K.S. pers. obs.), pupae of all species were also presented naked. Pupae were exposed individually to a 5-day-old mated female $B$. nosatoi for $4-5 \mathrm{~h}$ in a glass tube $(10.5 \times 2.5 \mathrm{~cm}$, Borosil $)$ and then kept in separate glass tubes until any parasitoids emerged and the development period was recorded. There were 10 replicates for each species of intercrop herbivores plus, for comparison, we also carried out 10 replicates using pupae of $O$. arenosella and 10 using pupae of the rice moth Corcyra cephalonica (Lepidoptera: Pyralidae), a factitious host of Brachymeria commonly used in mass-rearing facilities. Between host species differences in developmental period were tested for using ANOVA in GenStat. The residuals were homogenous and normally distributed (Bartlett's test: $\chi^{2}=4.13$, df $=4, P=0.389$; ShapiroWilk test: $W=0.975, P=0.377$ ). 
Table 2 Lepidopterans found on intercrops as potential hosts for Goniozus nephantidis and Brachymeria nosatoi

\begin{tabular}{|c|c|c|c|c|}
\hline \multirow[t]{2}{*}{ Lepidopteran family } & \multirow[t]{2}{*}{ Species } & \multirow[t]{2}{*}{ Host plants } & \multicolumn{2}{|l|}{ Parasitism $^{1}$} \\
\hline & & & G. nephantidis & B. nosatoi \\
\hline Arctidae & Amata passalis Fab. & Vigna unguiculata (L.) Walp. & No & - \\
\hline \multirow[t]{2}{*}{ Cochlididae } & Contheyla rotunda Hamp. & Cocos nucifera $\mathrm{L}$. & No & No \\
\hline & Latoia lepida Cram. & Cocos nucifera $\mathrm{L}$. & No & No \\
\hline \multirow[t]{2}{*}{ Hesperidae } & Gangara thyrsis Fab. & Cocos nucifera $\mathrm{L}$. & No & No \\
\hline & Suastus gremius $\mathrm{Fb}$. & Cocos nucifera $\mathrm{L}$. & No & - \\
\hline \multirow[t]{5}{*}{ Noctuidae } & Anadevidia peponis (Fb.) & Trichosanthes anguina $\mathrm{L}$. & No & No \\
\hline & Antoba olevaceae Wlk. & Solanum melongena $\mathrm{L}$. & No & No \\
\hline & Helicoverpa armigera $\mathrm{Hb}$. & $\begin{array}{l}\text { Vigna unguiculata (L.) Walp., Lycopersicum } \\
\text { esculentum Mill., Trichosanthes anguina } \mathrm{L} .\end{array}$ & No & No \\
\hline & Spodoptera litura $(\mathrm{Fb})$. & $\begin{array}{l}\text { Dioscorea alata L., Capsicum annuum L., Cucurbita } \\
\text { moschata (Duchesne ex Lam.), Colocasia } \\
\text { esculenta (L.) Schott. }\end{array}$ & No & No \\
\hline & Turnaca acuta $\mathrm{W}$. & Cocos nucifera $\mathrm{L}$. & No & No \\
\hline Pieridae & Catopsilia crocale Cramer & Cassia fistula $\mathrm{L}$. & No & No \\
\hline \multirow[t]{9}{*}{ Pyralidae } & Syllepte derogata $(\mathrm{Fb})$. & Abelmoschus esculentus (L.) Moench & Yes (failed ${ }^{2}$ ) & Yes \\
\hline & Herculia nigrivita Walker & Cocos nucifera $\mathrm{L}$. & Yes (failed ${ }^{2}$ ) & Yes \\
\hline & Cnaphalocrocis medinalis Guen. & Oryza sativa $\mathrm{L}$. & No & - \\
\hline & Diaphania indica Saund. & $\begin{array}{l}\text { Cucurbita moschata (Duchesne ex Lam.), } \\
\text { Trichosanthes anguina L., Cucumis sativus L. }\end{array}$ & No & No \\
\hline & Glyphodes glauculalis Guen. & Momordiaca charantia L. & No & - \\
\hline & Leucinodes orbonalis Guen. & Trichosanthes anguina L., Solanum melongena L. & No & - \\
\hline & Pilocrocis milvinalis & Cassia fistula $\mathrm{L}$. & No & No \\
\hline & Psara basalis F. & Amaranthus viridis $\mathrm{L}$. & No & - \\
\hline & Psara bipunctalis $\mathrm{Fb}$. & Solanum melongena $\mathrm{L}$. & No & - \\
\hline
\end{tabular}

${ }^{1}$ Results follow presentation of late-instar larvae to G. nephantidis females and naked pupae to B. nosatoi females

${ }^{2}$ Hosts were stung and paralyzed and eggs were laid but offspring failed to develop

\section{Construction of trophic webs for the coconut agro- ecosystem}

A preliminary literature survey had revealed that many of the parasitoids of $O$. arenosella were also reported on pests of several other crops. Hence, an extensive literature survey was carried out to compile field records for coconut and all the intercrops grown in coconut plantations in the Indian subcontinent, all of their lepidopteran herbivores and the primary parasitoids of these herbivores. The sources from which information was collected were: Dharmaraju (1952, 1962), Balasundaram and Aiyadurai (1963), Nelliat et al. (1974), Varghese et al. (1978), Mohamed et al. (1982), Abdurahiman et al. (1983), Bavappa et al. (1986), Cock and Perera (1987), Paul (2007), Fatma and Pathak (2011), Sasidharan (2011), Sharma (2011), Muniappan et al. (2012), Yu et al. (2012), Sithanantham et al. (2013) and Noyes (2015). We supplemented these sources with records reported on the following web sites: The Plant List (2013), Indian Council of Agricultural Research-National Bureau of Agricultural Insect
Resources (2013), Insects Catalog-Insecta.Pro (2007-2017), EPPO (2016).

These prior records were then used to compile composite connectance community webs (Memmott and Godfray 1994; Sunderland et al. 2005) of plant-herbivore and herbivoreparasitoid interactions within the coconut agro-ecosystem. Connectance, a proportional measure of community complexity, was calculated as the number of recorded herbivoreplant or parasitoid-herbivore interactions divided by the number of possible interspecific trophic interactions (Sunderland et al. 2005; Rocca and Greco 2015). We also quantified herbivore overlap and parasitoid overlap to indicate the degree to which sharing host plants and sharing natural enemies with intercrop herbivores might influence $O$. arenosella populations. Overlap was calculated as the number of pairs of species of plant, or herbivore, that shared at least one herbivore, or parasitoid, divided by the total possible number of such links (Sunderland et al. 2005). We also recorded the numbers of herbivore, or parasitoid, species that were shared between each linked pair of plants or herbivores, thus providing quantitative measures of overlap (van Veen et al. 2008). 


\section{Results}

\section{Field survey of intercrop plants}

Across the four locations, a total of 54 species of intercrop plants, belonging to 34 families, were observed (Table 1). With the exception of banana in a heavily infested coconut plantation in Cochin during November 2010 to May 2011, there were no observations of $O$. arenosella on any intercrops in any location either during the infestation or noninfestation periods. However, larvae of 20 other species of Lepidoptera were collected from the intercrop plants (see below).

\section{Screening of intercrop feeding by $\boldsymbol{O}$. arenosella larvae}

Opisina arenosella larvae fed on the leaves of 24 species of intercrops, but not on the other 30 species screened. Feeding rates differed significantly among the intercrop species which were fed on (Kruskal-Wallis test: $H=178.8, \mathrm{df}=23, P<0.001$, Fig. 3). The most fed on intercrop species were Artocarpus heterophyllus (Jack fruit), Elaeis guineensis (Oil palm) and Anacardium occidentale (Cashew), where feeding rates were approximately $30-45 \%$ of those observed on C. nucifera (Coconut) leaves. Leaves of all other intercrop species were fed on at rates lower than $20 \%$ of the rate of feeding on coconut; nonetheless, the leaves of around 10 further species also found to be acceptable to $O$. arenosella larvae (Fig. 3). However, it was also observed that feeding on Ananas comosus (Pineapple) and Terminalia catappa (Indian almond) led to premature pupation of some larvae.

\section{Performance of $\boldsymbol{O}$. arenosella feeding on intercrop plants}

The $O$. arenosella larvae constructed its characteristic gallery on jack fruit, cashew and oil palm exactly in the same manner as in coconut (Fig. 1). The adult moths that emerged appeared to be morphologically and physiologically normal. The larval period differed significantly across all four plant species presented and was shortest when on coconut (Table 3). Pupal periods were also shortest on coconut but did not differ among larvae fed on the three intercrops (Table 3). The longevity of adult females was unaffected by the species of plant on which larvae had fed (Table 3).

\section{Screening of intercrop herbivores as alternative hosts for parasitoids of $\boldsymbol{O}$. arenosella}

\section{Goniozus nephantidis}

Only three of the intercrop herbivore species presented were attacked by G. nephantidis females, all were members of the family Pyralidae (Table 2). While the larvae of H. nigrivita and Syllepte (=Sylepta) derogata were stung, paralyzed and had eggs laid on them, and the eggs hatched to larvae, the parasitoids did not complete development as the host either decayed or became desiccated within 2 days.

\section{Brachymeria nosatoi}

Of the 13 species of intercrop herbivores screened, $B$. nosatoi successfully parasitized the pupae of the Pyralid species H. nigrivita, S. derogata and Psara basalis (Table 2). The naked pupae of these three species were readily accepted, and the oviposition behaviour was the same as described by Mohamed et al. (1983) on O. arenosella pupae. Pupae of the factitious host $C$. cephalonica were also attacked similarly. The developmental period of $B$. nosatoi varied significantly across host species: development was most rapid on $O$. arenosella, slowest on Corcyra cephalonica and intermediate (and not significantly different) across the three intercrop herbivore species (Table 4).
Table 3 The mean developmental periods and adult longevity of $O$. arenosella reared on different plant species

\begin{tabular}{llll}
\hline Plant species & $\begin{array}{l}\text { Larval period } \\
(\text { days } \pm \text { SE) }\end{array}$ & $\begin{array}{l}\text { Pupal period } \\
\text { (days } \pm \text { SE) }\end{array}$ & $\begin{array}{l}\text { Adult female longevity } \\
\text { (days } \pm \text { SE) }\end{array}$ \\
\hline Artocarpus heterophyllus (Jackfruit) & $51.33 \pm 0.68^{\mathrm{a}}$ & $9.33 \pm 0.30^{\mathrm{a}}$ & $4.33 \pm 0.26$ \\
Anacardium occidentale (Cashew) & $47.14 \pm 0.46^{\mathrm{b}}$ & $9.00 \pm 0.33^{\mathrm{a}}$ & $4.71 \pm 0.40$ \\
Elaeis guineensis (Oil palm) & $42.60 \pm 0.91^{\mathrm{c}}$ & $8.60 \pm 0.31^{\mathrm{a}}$ & $4.00 \pm 0.37$ \\
Cocos nucifera (Coconut) & $36.20 \pm 0.96^{\mathrm{d}}$ & $7.00 \pm 0.30^{\mathrm{b}}$ & $4.72 \pm 0.367$ \\
$F_{(3,36)}$ & 68.679 & 10.948 & 0.941 \\
$P$ & $<0.001$ & $<0.001$ & 0.431 \\
\hline
\end{tabular}

For larval and pupal data, the superscript letters within columns indicate whether responses to each plant species were similar (assessed by aggregation of factor levels)

Statistical results are from ANOVA 


\section{Trophic webs}

The literature survey provided records for coconut plus 33 species of intercrops, 58 species of lepidopteran herbivores and 29 species primary parasitoids. Coconut was reported to be fed on by five herbivore species, its major pest $O$. arenosella plus Suastus gremius, Contheyla rotunda, Parasa lepida and Artona catoxantha (Fig. 4), while the number of herbivores feeding on intercrop species ranged between 1 and 8 (mean $=2.09)$. The connectance of the plant-herbivore trophic web was 0.038 (Fig. 4). Overall, the proportion of herbivore overlap between the plant species was low, 0.034, with around half of the plant species (14/34) not sharing any herbivores at all, although two pairs of plant species were linked by more than one herbivore (Table 5). Coconut shared a herbivore, $C$. rotunda, with only one intercrop species, oil palm, $E$. guineensis (Table 5).

The connectance of the herbivore-parasitoid trophic web (Fig. 5) was 0.112. Opisina arenosella was attacked by four species of egg parasitoids, six larval parasitoids and 13 pupal parasitoids (Fig. 5). Overall, the proportion of parasitoid overlap between the herbivore species was 0.472 (Table 6). Pairs of herbivore species that were linked by shared parasitism, shared an average of 1.611 species of parasitoids. O. arenosella shared a mean of 2.317 parasitoid species with each other herbivore species to which it was linked by parasitism (Table 6).

We further calculated overall overlap separately for egg, larval and pupal parasitism: egg parasitoid overlap was 0.303, larval parasitoid overlap was 0.086 and pupal parasitoid overlap was 0.203 . In terms of the numbers of parasitoids shared by pairs herbivores linked by parasitism, the mean number of shared egg parasitoid species was 1.381, mean shared number of larval parasitoids was 1.077 and mean shared pupal parasitoids was 1.235.

Table 4 The developmental period of B. nosatoi on different species of host pupae

\begin{tabular}{ll}
\hline Lepidopteran species & $\begin{array}{l}\text { Developmental period } \\
(\text { days } \pm \mathrm{SE})\end{array}$ \\
\hline Opisina arenosella & $12.5 \pm 0.269^{\mathrm{a}}$ \\
Corcyra cephalonica & $15.6 \pm 0.400^{\mathrm{b}}$ \\
Herculia nigrivita & $14.0 \pm 0.211^{\mathrm{c}}$ \\
Syllepte derogata & $13.7 \pm 0.335^{\mathrm{c}}$ \\
Psara basalis & $14.0 \pm 0.365^{\mathrm{c}}$ \\
$F_{(4,45)}$ & 11.710 \\
$P$ & $<0.001$ \\
\hline
\end{tabular}

Superscript letters indicate whether responses to each host species were similar (assessed by aggregation of factor levels)

Statistical results are from ANOVA

\section{Discussion}

Opisina arenosella can feed on several plant species that are planted as intercrops with coconut, for instance forming characteristic galleries of frass and silk when feeding on the leaves of jack fruit, cashew and oil palm. While banana was not fed on in the laboratory, the occurrence of $O$. arenosella on banana in a severely infested coconut plantation at Cochin, where jack fruit or cashew or oil palm were not available (S.K.S. pers. obs.), further illustrates that intercrop species may be utilized during severe pest outbreaks. However, others may be entirely unsuitable due to chemical or physical deterrents (e.g. Schuman et al. 2016; Zhang et al. 2017), which could account for the premature pupation of $O$. arenosella when fed on pineapple and Indian almond leaves. In all cases, the performance of $O$. arenosella on intercrops was lower than when feeding on coconut and it is seldom found feeding on intercrops in the field. As such, the role intercrops may play in the direct maintenance of $O$. arenosella populations does not seem likely to be substantial. Further, $O$. arenosella is unlikely to be in direct competition for resources with other lepidopterans originating from intercrops (which could lead to competitive exclusion, Reitz and Trumble 2002; van Veen et al. 2006a, 2008) as these herbivores do not typically feed on coconut.

Similarly, intercrops are unlikely to influence directly $G$. nephantidis, the major parasitoid of $O$. arenosella larvae, as it does not develop to maturity on the intercrop herbivores we screened. Goniozus nephantidis can, however, be reared on other factitious hosts belonging to several lepidopteran families (including the Pyralid C. cephalonica) and is widely used in the augmentative biological control of $O$. arenosella (Dharmaraju 1952; Nirula 1956; George et al. 1977; Remadevi et al. 1978, 1996; Mohamed et al. 1982; Sathiamma et al. 1987; Mohan and Shameer 2003; Rajan et al. 2009). The paralysis of, and oviposition on, $H$. nigrivita and $S$. derogata indicates that $G$. nephantidis may contribute to suppression of these intercrop herbivores by killing larvae, even if subsequent parasitism is unsuccessful. In contrast, B. nosatoi, a major parasitoid of $O$. arenosella pupae, that is also mass reared and released in the augmentative biocontrol (Joy and Joseph 1972, 1973; Sathiamma et al. 1987), is able to develop on the pupae of several species of intercrop herbivores: $S$. derogata, $H$. nigrivita and $P$. basalis were successfully parasitized in the laboratory. Brachymeria nosatoi readily accepted naked pupae of all the five pests in the laboratory and development of B. nosatoi on $S$. derogata, $H$. nigrivita (contra Mohamed et al. 1983) and development on P. basalis was significantly faster than on the commonly used factitious host $C$. cephalonica. Hence, the pupae of these three pest 


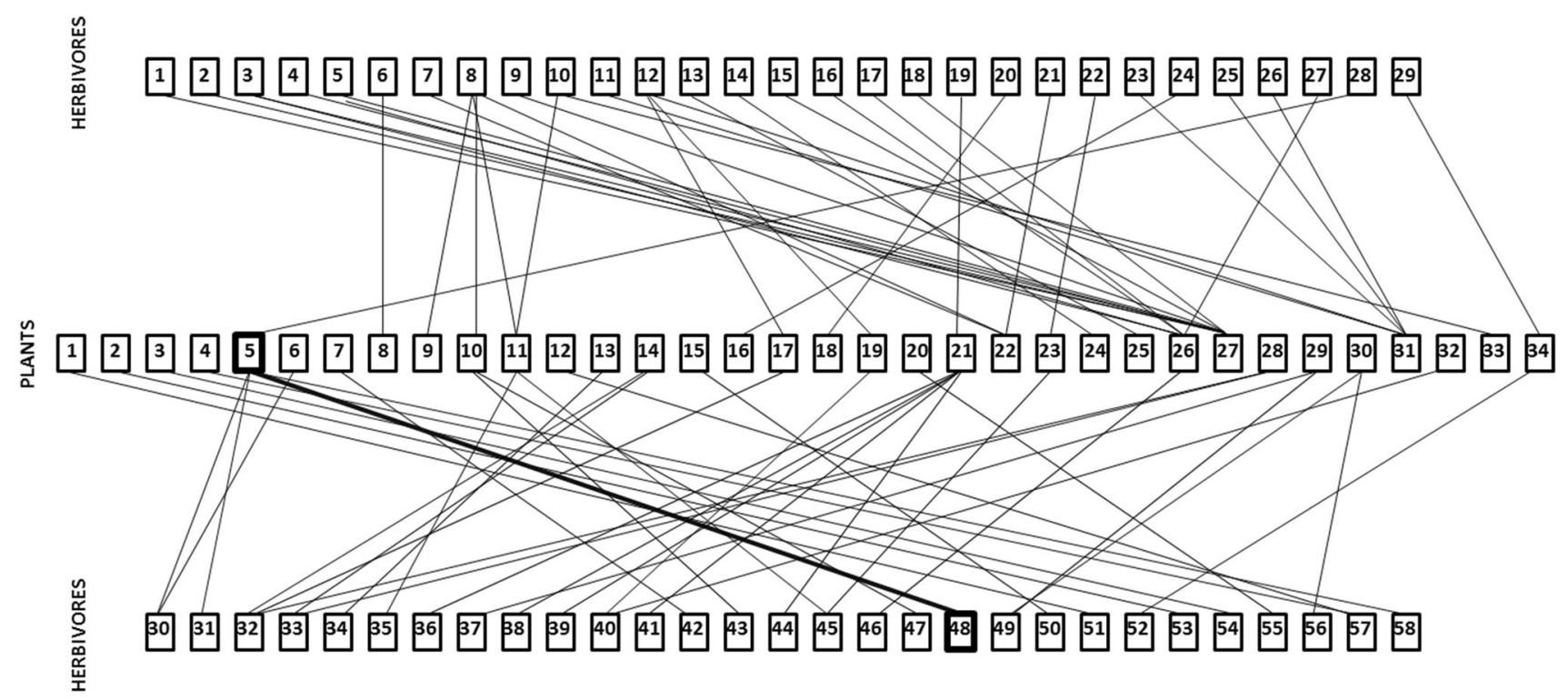

Fig. 4 Trophic interactions between plants and herbivores in coconut plantations. Composite connectance web summarizing herbivory within the coconut plantation community. Coconut (C. nucifera) is highlighted with a thick box, as is its major pest $O$. arenosella. All herbivores listed belong to the Lepidoptera. Plants. Amaranthaceae: 1. Amaranthus viridis L. Anacardiaceae: 2. Anacardium occidentale L., 3. Mangifera indica L. Araceae: 4. Amorphophalus paeonifolius (Dennst.) Nicolson. Arecaceae: 5. Cocos nucifera L., 6. Elaeis guineensis Jacq. Bromeliaceae: 7. Ananas comosus (L.). Caricaceae: 8. Carica papaya L. Cucurbitaceae: 9. Coccinia indica Wight \& Arn., 10. Cucumis sativus L., 11. Trichosanthes anguina L. Dioscoriaceae: 12. Dioscorea alata L. Euphorbiaceae: 13. Manihot esculenta Crantz., 14. Ricinus communis L. Fabaceae: 15. Acacia mangium Willd., 16. Arachis hypogea L., 17. Phaseolus spp., 18. Tamarindus indica L. 19. Vigna unguiculata (L.) Walp. Lamiaceae: 20. Ocimum tenuiiflorum L. Malvaceae: 21. Abelmoschus esculentus (L.) Moench. Moraceae: 22. Artocarpus heterophyllus Lam., 23. Morus alba L. Moringaceae: 24. Moringa oleifera Lam. Musaceae: 25. Musa paradisiaca L. Poaceae: 26. Oryza sativa L., 27. Saccharum officinarum L. Punicaceae: 28. Punica granatum L. Rubiaceae: 29. Ixora javanica (Blume) DC. Rutaceae: 30. Citrus $\times$ aurantifolia (Chistm. \& Panz.) Swingle. Solanaceae: 31. Capsicum annuum L., 32. Lycopersicum eseulentum Mill. 33. Solanum melongena L.Verbenaceae: 34. Tectona grandis L. Herbivores. Crambidae: 1. Chilo infuscatellus Snellen, 2. Chilo partellus (Swinhoe), 3. Chilo polychrysus (Meyrick), 4. Chilo sacchariphagus indicus (Kapur), 5. Chilo suppressalis Walker, 6. Conogethes punctiferalis (Guenée), 7. Diaphani acaesalis (Walker),

species can be utilized for the mass multiplication of $B$. nosatoi in the laboratory. The acceptance of naked pupae of $C$. cephalonica by $B$. nosatoi is advantageous for the laboratory multiplication of this parasitoid given the fact that $C$. cephalonica can be easily reared in the laboratory. Our empirical results suggest that intercrops can harbour populations of $B$. nosatoi and thus also that $O$. arenosella and intercrop herbivores may interact indirectly via shared B. nosatoi parasitism.

Trophic webs constructed from literature evidence similarly suggest that intercrop plants share relatively few lepidopteran herbivores among themselves or with coconut
8. Diaphania indica (Saunders), 9. Diatraea saccharalis (Fabricius), 10. Leucinodes orbonalis Guenée, 11. Maruca sp., 12. Maruca vitrata (Fabricius), 13. Nacoleia octasema (Meyrick), 14. Noorda moringae Tams, 15. Scirpophaga excerptalis (Walker), 16. Scirpophaga incertulas (Walker), 17. Scirpophaga innotata (Walker), 18. Scirpophaga nivella (Fabricius), 19. Syllepte derogate Fabricius. Erebidae: 20. Dasychira sp., 21. Perina nuda (Fabricius), 22. Spilosoma obliqua (Walker), 23. Utetheisa pulchella (Linnaeus). Gelechiidae: 24. Aproaerema modicella Deventer, 25. Pectinophora gossypiella (Saunders), 26. Phthorimaea operculella (Zeller). Hesperiidae: 27. Pelopidas mathias (Fabricius), 28. Suastus gremius (Fabricius). Hyblaeidae: 29. Hyblaea puera (Cramer). Limacodidae: 30. Contheyla rotunda Hampson, 31. Parasa lepida Cramer. Noctuidae: 32. Achaea janata (Linnaeus), 33. Achaea sp., 34. Agrotis ipsilon (Hufnagel), 35. Anadevidia peponis (Fabricius), 36. Anomis flava (Fabricius), 37. Chrysodeixis includens (Walker), 38. Earias insulana Boisduval, 39. Earias vittela (Fabricius), 40. Helicoverpa armigera (Hübner), 41. Helicoverpa zea (Boddie), 42. Mythimna sp., 43. Peridroma saucia (Hübner), 44. Spodoptera exigua Hübner, 45. Spodoptera litura (Fabricius), 46. Spodoptera mauritia (Boisduval), 47. Trichoplusia ni (Hübner). Oecophoridae: 48. Opisina arenosella Walker. Papilionidae: 49. Papilio polytes. Pieridae: 50. Eurema sp. Plutellidae: 51. Plutella xylostella (Linnaeus). Pyralidae: 52. Eutectona machaeralis (Walker), 53. Lamida moncusalis Walker, 54. Orthaga exvinacea (Hampson). Saturniidae: 55. Antheraea mylitta (Drury). Sphingidae: 56. Agrius convolvuli (Linnaeus), 57. Hippotion celerio (Linnaeus). Zygaenidae: 58. Artona catoxantha Hampson

but that there is a considerable degree of natural enemy sharing among intercrop herbivores and $O$. arenosella. In terms of the number of species involved, the sharing of egg and pupal parasitoids is more prevalent in the agroecosystem than is the sharing of larval parasitoids. We suggest that this may reflect a greater degree of co-evolutionary intimacy (e.g. involving host immune responses and parasitoid countermeasures) between larval parasitoids and their hosts than between egg- or pupal parasitoids and their hosts (see also van Veen et al. 2008 for an analogous argument). Goniozus nephantidis appears to be monophagous within the agro-ecosystem (despite having a 
Table 5 Herbivore overlap among coconut and the 33 species of intercrops

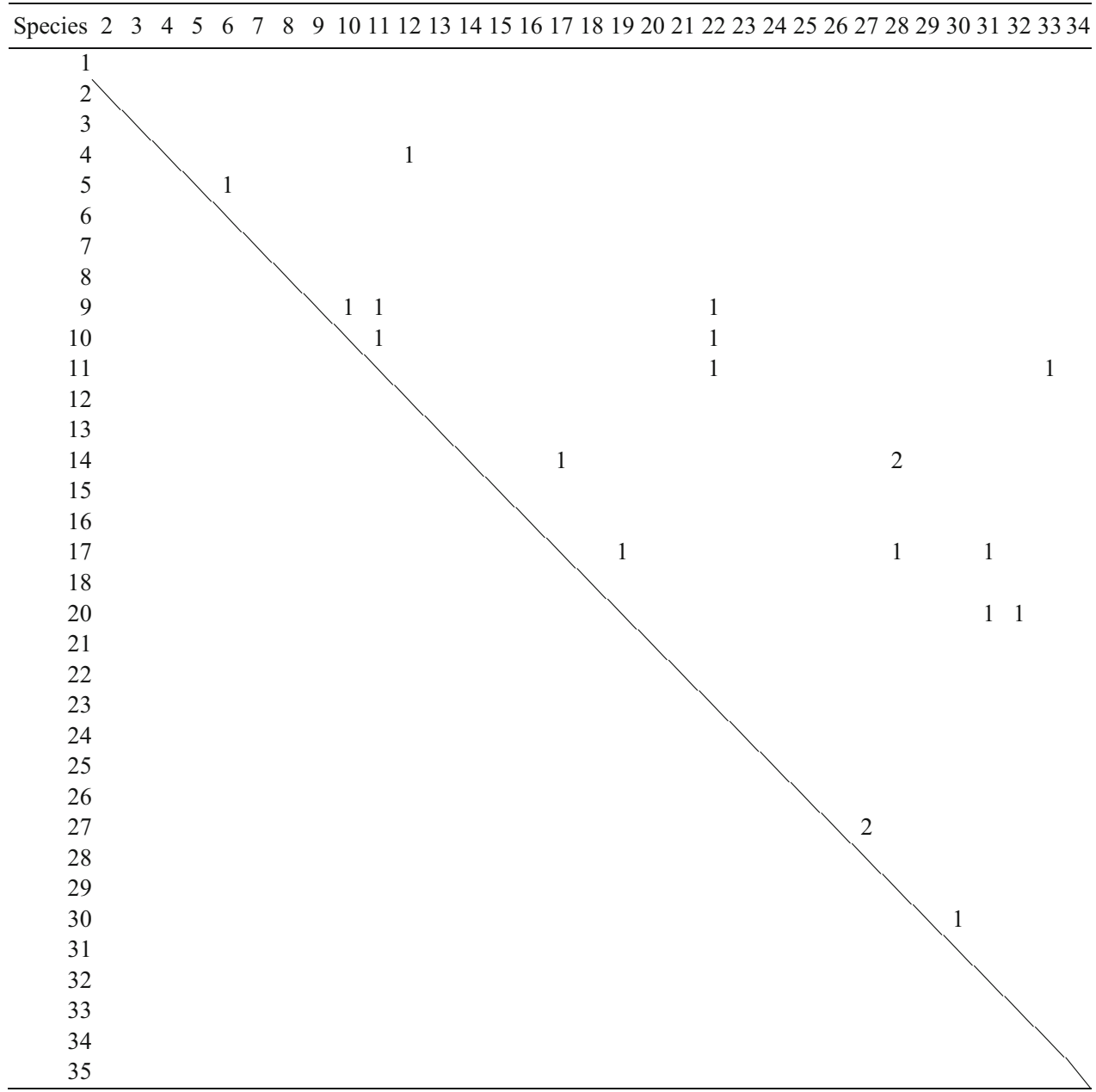

The numbers of herbivore species shared between each possible pair of plants are shown. The proportion of pairs sharing at least one herbivore was 0.034. Plant species identities are as given in Fig. 4

number of factitious laboratory hosts, see above) and Elasmus nephantidis, which is recommended for field release against $O$. arenosella (Sathiamma et al. 1987), and the larval-pupal parasitoid Meteoridea hutsoni, which is commonly found in infested palms, are also not reported from any intercrop herbivores. However, Apanteles taragamae, a solitary endoparasitoid of second and third instar $O$. arenosella larvae, is commonly found in infested coconut plantations and also attacks the larvae of $\mathrm{Di}$ aphania indica which infests Coccinia grandis and $\mathrm{Cu}$ cumis sativus L., vegetable crops which are often intercrops of coconut. Egg parasitoids appear to be considerably less host specific. For instance, Trichogramma chilonis, T. minutum and T. evanescens, which are parasitoids of $O$. arenosella eggs (Mohamed et al. 1982), also attack 26, 20 and 11 species of intercrop herbivores, respectively. Similarly, a number of pupal parasitoids of $O$. arenosella can be reared on other lepidopteran host species (Kabeerathumma and Nair 1971; Nadarajan and Jayaraj 1975; Pillai and Nair 1987; Baitha et al. 2003). For example, five species of Brachymeria, which are pupal parasitoids of $O$. arenosella, can develop on many of the intercrop herbivores (Joy et al.1978; Mohamed et al. 1982, 1983; Streito and Nibouche 1997); in particular, $B$. nosatoi was reported from $C$. punctiferalis (infesting $C$. papaya) and Pectinophora gossypiella (infesting Capsicum annuиm). Biocontrol practitioners have observed that $B$. nosato $i$ is often the first parasitoid species to reach new $O$. arenosella outbreaks (Pers. Comm. from staff of the Coconut Research Institute, Lunuwila, Sri Lanka) and this characteristic may be promoted by its ability to develop on these intercrop herbivores.

Our estimates of trophic web connectance between plants and herbivores (0.038) and between herbivores and 


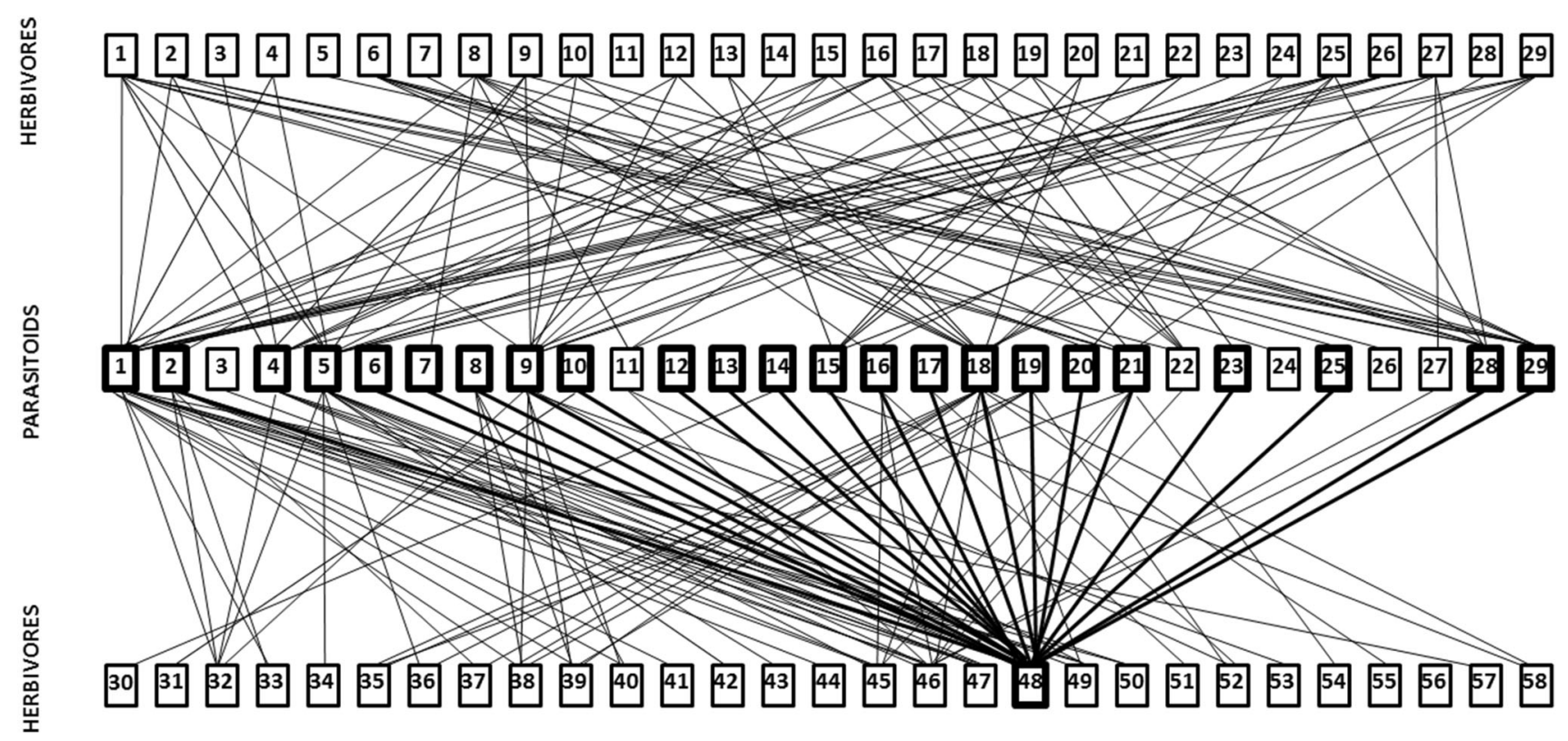

Fig. 5 Trophic interactions between herbivores and parasitoids in coconut plantations Composite connectance web summarizing the Herbivore-Parasitoid complex within the coconut plantation community. The coconut caterpillar $O$. arenosella and its parasitoids are highlighted with thick boxes and bold lines. Herbivores: All belong to Lepidoptera, as given in Fig. 4. Egg Parasitoids. Trichogrammatidae: 1. Trichogramma chilonis Ishii, 2. Trichogramma evanescens Westwood, 3. Trichogramma exiguum Pinto \& Platner, 4. Trichogramma japonicum Ashmead, 5. Trichogramma minutum Riley. Larval Parasitoids. Bethylidae: 6. Goniozus nephantidis (Musebeck). Braconidae: 7. Apanteles taragamae Viereck, 8. Bracon brevicornis Wesmael, 9. Bracon hebetor Say, 10. Fornicia ceylonica Wilkinson.

parasitoids (0.112) are lower than values reported from a cropping system recently introduced into the new world and containing a small number of species $(0.39$, among 4 host and 6 parasitoid species, Rocca and Greco 2015). This may be due to a false working assumption that all plant, Lepidopteran and parasitoid species all belong to the same ecological community (Poulin 2010), essentially delineated by planation boundaries. Our connectance estimates are, however, similar to some values reported for natural communities of herbivores and parasitoids (0.06-0.10, among 45 hosts and 31 parasitoids, Maunsell et al. 2015). One interpretation could be that parasitoid trophic webs in coconut plantations are, in fact, naturalistic due to this being a long-established agro-ecosystem. Cross-study comparisons between connectance estimates must, however, be made with caution as values are sensitive to sampling limitations, which will increase mechanistically in larger webs and may explain the lower estimates among webs containing more species (Blüthgen 2010; Poulin 2010).

Although our empirical and literature-based evaluations do not assess the population densities of the insect species in the agro-ecosystem or quantify the strengths of
Eulophidae: 11. Elasmus brevicornis Gahan, 12. Elasmus nephantidis Rohwer. Pupal Parasitoids. Braconidae: 13. Meteoridea hutsoni Nixon. Chalcididae: 14. Antrocephalus hakonensis Ashmead, 15. Brachymeria euploeae Westwood, 16. Brachymeria excarinata Gahan, 17. Brachymeria hime atteviae Joseph, Narendran \& Joy, 18. Brachymeria lasus Walker, 19. Brachymeria nephantidis Gahan, 20. Brachymeria nosatoi Habu. Eulophidae: 21. Tetrastichus howardi Olliff, 22. Tetrastichus schoenobii, 23. Trichospilus pupivorus Ferrière. Ichneumonidae: 24. Eriborus ricini Rao \& Kurian, 25. Eriborus trochanteratus Morely, 26. Trathala flavoorbitalis Cameron, 27. Xanthopimpla flavolineata Cameron, 28. Xanthopimpla punctata Fabricius, 29. Xanthopimpla stemmator Thunberg

interactions in the trophic web (Memmott and Godfray 1994; Valladares and Salvo 1999; Sunderland et al. 2005; Maunsell et al. 2015; Rocca and Greco 2015), current evidence suggests that indirect ecological interactions, such as apparent competition (Holt and Lawton 1993; Müller and Godfray 1997; van Veen et al. 2006a,b, 2008; Jaworski et al. 2015), via shared parasitoids could influence populations of $O$. arenosella when intercrops are present. Apparent competition may ultimately exclude all but one herbivore species from a community and the dominant (remaining) species may be that which supports the highest density of parasitoids (Holt and Lawton 1993; van Veen et al. 2006a). In terms of number of species (the connectance trophic web, Fig. 5, provides no measures of densities), $O$. arenosella is a host of 23 of the 29 parasitoids in the agro-ecosystem, substantially more than any of the other lepidopterans recorded, which suggests that $O$. arenosella may be affected, but perhaps not excluded, by apparent competition, during periods of infestation. Further, the presence of apparent competition in agroecosystems does not necessarily reduce pest damage (Jaworski et al. 2015). The potential for intercrop herbivores to sustain parasitoids of $O$. arenosella during non- 
Table 6 Parasitoid overlap among herbivores

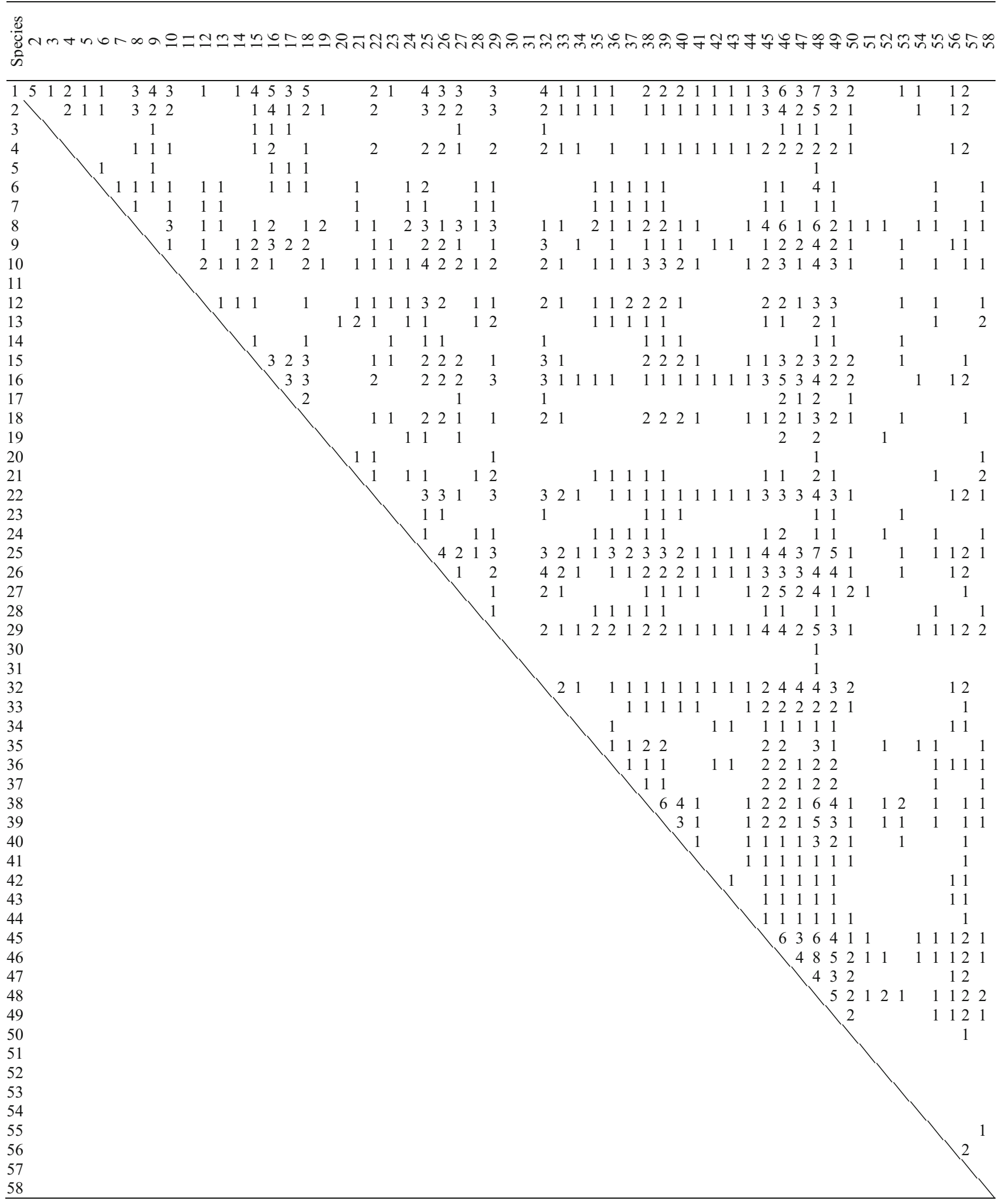

The numbers of parasitoid species shared between each possible pair of herbivores species are shown. The proportion of pairs sharing at least one parasitoid is 0.472 . Herbivore species identities are as given in Fig. 4 
infestation periods is, however, clear and this is likely to promote pest suppression by decoupling parasitoid populations from the constraining seasonality of $O$. arenosella availability (Settle et al. 1996; Holt and Hochberg 2001; Clementine et al. 2005; Feng et al. 2017). In other agroecosystems, specialist insect herbivores have been shown to exhibit lower population densities in diverse habitats containing host and non-host plants compared with simple habitats containing host plants only (Kareiva 1983; Risch et al. 1983; Stanton 1983; Andow 1988). As parasitoids specialized on each of the developmental stages (egg, early instar larvae, late-instar larvae, pupal) of $O$. arenosella are shared with intercrop herbivores, detrimental interspecific competition between parasitoids (Hardy and Blackburn 1991; Denoth et al. 2002) may be reduced and pest populations may be additively suppressed (Hassell 1978; Kindlman and Ruzicka 1992).

Attaining an understanding of the composition and dynamics of ecological and agro-ecological communities is extremely challenging, as the forms and strengths of species interactions are varied and complex (e.g. Watt 1965; Paine 1992; Holt and Lawton 1993; Wilson et al. 1996; Valladares and Salvo 1999; Holt and Hochberg 2001; van Veen et al. 2006a; Poulin 2010; Allesina and Tang 2012; Jaworski et al. 2015; Levine et al. 2017). The information we provide and synthesize here can at present serve only as a tentative guide towards more detailed understanding of the dynamics of the coconut agro-ecosystem. The literature records we compile may be biased due to greater attention having paid to some species than to others. The construction of semi-quantitative or quantitative trophic webs directly from field observations would constitute a desirable extension of this work, as would the inclusion of non-lepidopteran herbivores, predators, pathogens, and hyper-parasitoids into these webs (Memmott and Godfray 1994; Valladares and Salvo 1999; van Veen et al. 2006a, 2008; Maunsell et al. 2015; Rocca and Greco 2015). An understanding of why given parasitoid species attack some intercrop herbivores, but not others could be gained by metabolomic analysis (Snart et al. 2015) to identify biochemical differences between herbivore species, or tri-trophic effects of the host plants fed upon (Bukovinszky et al. 2008; Schuman et al. 2016), that might prevent extreme polyphagy and thus the wider sharing of natural enemies. Further, direct observations that parasitoids developing on intercrop herbivores subsequently attack $O$. arenosella would provide key evidence for whether coconut and its intercrops form single or segregated habitats (Feng et al. 2017).

Since the practice of intercropping/mixed cropping in large-scale coconut plantations and homestead gardens is very common, the recommendation of specific crops or plants to be grown along with coconut in the context of beneficial plant-herbivore-parasitoid associations is likely to aid the conservation biocontrol of $O$. arenosella. Indeed, from our own experience in Kerala (near Alappuzha) it seems that $O$. arenosella infestations are less severe in areas with intercrops than in those without (pers. obs. S.K.S \& C.M.), and we note that these observations accord with the conclusions of recent meta-analyses across a wide range of agro-ecosystems (Letourneau et al. 2011; Iverson et al. 2014). We recommend the following intercrops to be grown in coconut plantations because of their support for major parasitoids of $O$. arenosella (parasitoids are in parenthesis): Cucumis sativus (T. minutum, A. taragammae, B. lasus, X. punctata), Morus alba (T. minutum, B. lasus), Oryza sativa (T. minutum, B. lasus, X. punctata), Saccharum officinarum (T. minutum, B. hebetor, X. punctata), Tectona grandis (T. minutum, B. lasus), Abelmoschus esculentus (T. minutum, B. hebetor, B. lasus, X. punctata), Capsicum annuum (T. minutum, B. hebetor, B. lasus, B. nosatoi, X. punctata), Citrus aurantifolia (T. minutum, B. hebetor), Ricinus communis (T. minutum, B. hebetor), Coccinia grandis (A. taragammae, B. lasus, X. punctata), Trichosanthes anguina (B. hebetor, B. lasus), Carica papaya (B. lasus, B. nosatoi) and Solanum melongena (B. lasus, $X$. punctata). Not every plant species will be suited to every coconut plantation, for example due to variation in soil types and water profiles, but growing at least some of these plants is expected to be beneficial. Further work will be required to establish whether and how different combinations of intercrops might affect the population biology of $O$. arenosella.

\section{Conclusions}

Our empirical evaluations and the construction of trophic webs from prior literature both suggest that the presence of intercrops will not greatly affect $O$. arenosella populations, either by providing substantial alternative food sources for this pest species or by promoting direct herbivore-herbivore competition between the pest and other lepidopterans. In contrast, the high degree of parasitoid overlap between the herbivores present indicates that indirect competitive interactions, such as apparent competition, are likely play an important role in the coconut agro-ecosystem. These patterns accord with conclusions drawn by a number of prior studies of natural and semi-natural communities of phytophagous insects (van Veen et al. 2006a, b). The dynamics of multi-species host-parasitoid communities in nature and in agro-ecosystems are expected to be complex and inferences concerning the effects of shared parasitoids are thus constrained to be tentative. Current evidence nonetheless seems sufficient to allow us to recommend a number of intercrop species that are most likely to promote the suppression of $O$. arenosella via indirect ecological 
interactions, although we recognize that it may not be practicable to grow intercrops in all areas where coconut is cultivated and that any effects of different combinations of intercrops remain unexplored. Intercrops are most likely to exert an influence by maintaining populations of parasitoids during seasons in which $O$. arenosella at stages suitable for parasitism are scarce. While intercrops may not enhance natural enemy action in every agro-ecosystem, we consider it likely that our inferences will apply to other cropping systems in addition to coconut.

\section{Author contribution}

Shameer K.S. gathered the empirical and trophic web data, analysed the data and wrote the manuscript. Nasser M. instigated the research and commented on the manuscript. Chandrika Mohan discussed the data and commented on the manuscript. I.C.W. Hardy analysed the data and wrote the manuscript.

Acknowledgements We thank Ranjith A.P. for help in compilation of intercrops data and Mike Beard for help with some of the figures. We thank Nimali Inoka Suwandharathne, A.D.N.T. Kumara and others at the Coconut Research Institute, Lunuwila, Sri Lanka, for helpful discussion, and two anonymous referees for useful comments. The preparation of this paper at the University of Calicut was assisted by Erasmus+ staff mobility funding to I.C.W.H.

\section{Compliance with ethical standards}

Conflict of interest The visit of I.C.W.H. to the University of Calicut was assisted by Erasmus+ staff mobility funding awarded to the University of Nottingham. The authors declare that they have no further known conflicts of interest to declare. All applicable international, national and institutional guidelines for the care and use of animals were followed.

Open Access This article is distributed under the terms of the Creative Commons Attribution 4.0 International License (http://crea tivecommons.org/licenses/by/4.0/), which permits unrestricted use, distribution, and reproduction in any medium, provided you give appropriate credit to the original author(s) and the source, provide a link to the Creative Commons license, and indicate if changes were made.

\section{References}

Abdurahiman UC, Mohamed UVK, Remadevi OK (1983) Studies on the biology of Antrocephalus hakonensis (Hymenoptera: Chalcididae), a pupal parasitoid of Opisina arenosella, the coconut caterpillar. COCOS 1:11-16

Allesina S, Tang S (2012) Stability criteria for complex ecosystems. Nature 483:205-208

Andow DA (1988) Management of weeds for insect manipulation in agroecosystems. In: Altieri MA, Liebman MZ (eds) Weed management in agroecosystems: ecological approaches. CRC, Boca Raton, pp 265-301
Atakan E, Uygur S (2005) Winter and spring abundance of Frankliniella spp. and Thrips tabaci Lindeman (Thysan., Thripidae) on weed host plants in Turkey. J Appl Entomol 129:17-26

Baitha A, Jalali SK, Rabindra RJ, Venkatesan T, Rao NS (2003) Host preference of the pupal parasitoid, Tetrastichus howardi (Olliff) (Hymenoptera: Eulophidae). J Entomol Res 27:293-296

Balasundaram EK, Aiyadurai SG (1963) Grow spice crops in the shade of coconut palms. Cocon Bull 17:182-184

Bavappa KVA, Abdul Kader KV, Biddappa CC, Khan HH, Kasturi Bai KV, Ramadasan A, Sundararaju P, Bopaiah BM, Thomas GV, Misra LP, Balasimha D, Bhat NJ, Shama Bhat K (1986) Coconut and areca nut based high-density multispecies cropping system. J Plantn Crops 14:74-87

Blüthgen N (2010) Why network analysis is often disconnected from community ecology: a critique and an ecologist's guide. Basic Appl Ecol 11:185-195

Bukovinszky T, van Veen FJF, Jongema Y, Dicke M (2008) Direct and indirect effects of resource quality on food web structure. Science 319:804-807

Butani DK (1975) Insect pests of fruit crops and their control-15: date palm. Pesticides 9:40-42

Clementine D, Antoine S, Herve B, Kouahou FB (2005) Alternative host plants of Clavigralla tomentosicollis Stal (Hemiptera: Coreidae), the pod sucking bug of cowpea in the Sahelian zone of Burkina Faso. J Entomol 2:9-16

Cock MJW, Perera PACR (1987) Biological control of Opisina arenosella Walker (Lepidoptera, Oecophoridae). Biocontrol News Inf 8:283-310

Crawley MJ (1993) GLIM for ecologists. Blackwell Scientific Publications, Oxford

Denoth M, Frid L, Myers JH (2002) Multiple agents in biological control: improving the odds? Biol Control 24:20-30

Dharmaraju E (1952) The biological control of the black headed caterpillar of coconut (Nephantis serinopa Meyr) in the East Godavari district of Madras State. Indian Coconut J 5:171-175

Dharmaraju E (1962) A check list of parasites, the hyperparasites, predators and pathogens of the coconut leaf caterpillar Nephantis serinopa Meyrick, recorded in Ceylon and in India and their distribution in these countries. Ceylon Coconut Quart 13:102-111

EPPO (2016) EPPO global database. https://gd.eppo.int/. Accessed 8 Nov 2016

Fatma Z, Pathak PH (2011) Foodplants of Helicoverpa armigera (Hübner) and extent of parasitism by its parasitoids Trichogramma Chilonis Ishii and Campoletis chlorideae Uchida-a field study. Int J Entomol 2:31-39

Feng Y, Kravchuk O, Sandhu H, Wratten SD, Keller MA (2017) The activities of generalist parasitoids can be segregated between crop and adjacent non-crop habitats. J Pest Sci 90:275-286

Foale M (2003) The coconut odyssey: the bounteous possibilities of the tree of life. ACIAR Monogr 101:p132

George TG, Sahasranaman KN, George MV (1977) Note on natural parasitism of Nephantis serinopa Meyrick. Curr Res 6:27-28

Goodell PB (2009) Fifty years of the integrated control concept: the role of landscape ecology in IPM in San Joaquin valley cotton. Pest Manag Sci 65:1293-1297

Hardy ICW, Blackburn TM (1991) Brood guarding in a bethylid wasp. Ecol Entomol 16:55-62

Hassell MP (1978) The dynamics of arthropod predator-prey systems. Princeton University Press, Princeton

Hegde MR, Yusuf M, Gopalasundaram P (1993) Intercropping of vegetables in coconut garden. In: Nair MK, Khan HH, Gopalasundaram P, Baskara Rao EVV (eds) Advances in coconut research and development, Indian soc plantn crops. IBH Pub Co Pvt Ltd, Oxford, pp 407-412 
Holt RD, Hochberg ME (2001) Indirect interactions, community modules and biological control: a theoretical perspective. In: Wajnberg E, Scott JK, Quimby PC (eds) Evaluating indirect ecological effects of biological control. CABI Publishing, Wallingford, pp 13-80

Holt RD, Lawton JH (1993) Apparent competition and enemy-free space in insect host-parasitoid communities. Am Nat 142:623-645

Indian Council of Agricultural Research-National Bureau of Agricultural Insect Resources (2013) www.nbair.res.in/insectpests/

Insects Catalog-Insecta.Pro (2007-2017) Insecta.pro: international entomological community. Insect.pro/search/

Iverson AL, Marín LE, Ennis KK, Gonthier DJ, Connor-Barrie BT, Remfert JL, Cardinale BJ, Perfecto I (2014) Do polycultures promote win-wins or trade-offs in agricultural ecosystem services? A meta-analysis. J Appl Ecol 51:1593-1602

Jaworski CC, Chailleux A, Bearez P, Desneux N (2015) Apparent competition between major pests reduces pest population densities on tomato crop, but not yield loss. J Pest Sci 88:793

Joy PJ, Joseph KJ (1972) Note on a new host record of Brachymeria excarinata Gahan and first record of Brachymeria (Neobrachymeria) nosatoi Habu (Hymenoptera: Chalcididae) in India. Indian J Agric Sci 42:637-638

Joy PJ, Joseph KJ (1973) Notes on the biology of Brachymeria (Neobrachymeria) nosatoi and its importance in the control of Nephantis serinopa. Entomophaga 18:317-319

Joy PJ, Narendran TC, Joseph KJ (1978) Biology of Brachymeria nephantidis Gahan and Brachymeria lasus (Walker) (Hymenoptera: Chalcididae). Agric Res J Kerala 16:39-42

Kabeerathumma S, Nair MRGK (1971) Optimum superparasitism for the mass breeding of Trichospilus pupivora F. Agric Res J Kerala 9:101-102

Kareiva P (1983) Influence of vegetation texture on herbivore populations: resource concentration and herbivore movement. In: Denno RF, McClure MS (eds) Variable plants and herbivores in natural and managed systems. Academic, New York, pp 259-289

Kindlman P, Ruzicka Z (1992) Possible consequences of a specific interaction between predators and parasites of aphids. Ecol Model 61:253-265

Koji S, Fujinuma S, Midega CAO, Mohamed HM, Ishikawa T, Wilson MR, Asche M, Degelo S, Adati T, Pickett JA, Khan ZR (2012) Seasonal abundance of Maiestas banda (Hemiptera: Cicadellidae), a vector of phytoplasma, and other leafhoppers and planthoppers (Hemiptera: Delphacidae) associated with napier grass (Pennisetum purpureum) in Kenya. J Pest Sci $85: 37-46$

Kumara ADNT, Chandrashekharaiah M, Subaharan K, Chakravarthy AK (2015) Periodicity of adult emergence and sexual behaviour of coconut black headed caterpillar, Opisina arenosella Walker (Lepidoptera: Oecophoridae). Phytoparasitica 43:701-712

Letourneau DK, Armbrecht I, Salguero Rivera B, Montoya Lerma J, Jiménez Carmona E, Constanza Daza M, Escobar S, Galindo V, Gutiérrez C, Duque López S, López Mejía J, Acosta Rangel AM, Herrera Rangel J, Rivera L, Saavedra CA, Torres AM, Reyes Trujillo A (2011) Does plant diversity benefit agroecosystems? A synthetic review. Ecol Appl 21:9-21

Levine JM, Bascompte J, Adler PB, Allesina S (2017) Beyond pairwise mechanisms of species coexistence in complex communities. Nature 546:56-64

Manjunath TM (1985) Coconut black-headed caterpillar on banana and coconut. FAO Plant Prot Bull 33:71-72

Maunsell SC, Kitching RJ, Burwell CJ, Morris RJ (2015) Changes in host-parasitoid food web structure with elevation. J Anim Ecol 84:353-363
Memmott J, Godfray HCJ (1994) The use and construction of parasitoid webs. In: Hawkins BA, Sheehan W (eds) Parasitoid community ecology. Oxford University Press, Oxford, pp 300-318

Mohamed UVK, Abdurahiman UC, Remadevi OK (1982) Coconut caterpillar and its natural enemies: a study of the parasites and predators of Nephantis serinopa Meyrick. Zoological Monograph No.2, University of Calicut, Kerala, p 162

Mohamed UVK, Abdurahiman UC, Remadevi OK (1983) Bioethology of Brachymeria (Neobrachymeria) nosatoi (Chalcididae: Hymenoptera) a pupal parasite of the coconut pest Nephantis serinopa (Xylorictidae: Lepidoptera). J Sci Res 5:147-151

Mohan C, Shameer KS (2003) Galleria mellonella L. (Lepidoptera: Galleridae) as a new host for Goniozus nephantidis Mues (Hymenoptera: Bethylidae). Entomon 28:169-172

Mohan C, Sujatha A (2006) The Coconut leaf caterpillar, Opisina arenosella Walker. CORD (Special Issue) 22:25-78

Mohan C, Nair CPR, Kesavan Nampootihri C, Rajan P (2010) Leafeating caterpillar (Opisina arenosella) induced yield loss in coconut palm. Int J Tropic Insect Sci 30:132-137

Müller C, Godfray HCJ (1997) Apparent competition between two aphid species. J Anim Ecol 66:57-64

Muniappan R, Shepard BM, Carner GR, Ool PAC (2012) Arthropod pests of horticultural crops in tropical Asia. CAB International, Wallingford

Murthy KS, Gour TB, Reddy DDR, Babu TR, Zaheeruddeen SM (1995) Host preference of coconut black headed caterpillar Opisina arenosella Walker for oviposition and feeding. J Plant Crops 23:105-108

Nadarajan L, Channabasavanna GP (1980) Population dynamics of coconut black headed caterpillar, Nephantis serinopa Meyrick (Lepidoptera: Cryptophasidae) and its parasites. Mysore J Agric Sci 14:533-541

Nadarajan L, Jayaraj S (1975) Influence of various hosts on the development and reproduction of the pupal parasite, Tetrastichus israeli M. \& K. (Eulophidae: Hymenoptera). Curr Sci 44:458-460

Narendran TC, Abdurahiman UC, Mohamed UVK, Knutson L (1978) Field incidence of Nephantis serinopa in the Malabar area of Kerala state. Indian J Plant Prot 6:91-92

Nelliat EV, Bavappa KVA, Nair PKR (1974) Multistoried croppingnew dimensions of multiple cropping in coconut plantations. Wld Crops 26:262-266

Nirula KK (1956) Investigation on the pests of coconut palm. Part III: Nephantis serinopa Meyrick. Indian Coconut J 9:101-131

Noyes JS (2015) Universal chalcidoidea database. Available from: http://www.nhm.ac.uk/our-science/data/chalcidoids/database/ indexNamedHost.dsml. Accessed 23 Oct 2015

Paine RT (1992) Food-web analysis through field measurement of per capita interaction strength. Nature 355:73-75

Paul NAV (2007) Insect Pests and their Management. Division of Entomology, Indian Agricultural Research Institute, New Delhi, p 68

Pillai GB, Nair KR (1987) Observations on Xanthopimpla sp. (Hymenoptera: Ichneumonidae), a pupal parasite of Opisina arenosella Wlk on coconut in Kerala. J Biol Control 1:7-10

Poulin R (2010) Network analysis shining light on parasite ecology and diversity. Trends in Parasitol 26:492-498

Power AG (1987) Plant community diversity, herbivore movement, and an insect-transmitted disease of maize. Ecology 68:1658-1669

Rajan P, Mohan C, Nair CPR, Rajkumar AJ (2009) Integrated pest management in coconut. Technical Bulletin 55, Central Plantation Crops Research Institute, Kayamkulam, Kerala 
Rao RY, Cherian MC, Ananthanarayanan KP (1948) Investigations on Nephantis serinopa Meyr, in South India and their control by the biological method. Indian J Entomol 10:205-247

Reitz SR, Trumble JT (2002) Competitive displacement among insects and arachnids. Annu Rev Entomol 47:435-465

Remadevi OK, Mohamed UVK, Abdurahiman UC, Narendran TC (1978) Oviposition behaviour of Perisierola nephantidis Muesebeck (Bethylidae: Hymenoptera) a larval parasite of Nephantis serinopa Meyrick (Xylorictidae: Lepidoptera). Entomon 3:303-305

Remadevi OK, Abdurahiman UC, Sasidharan TO (1996) Notes on the host range of Goniozus nephantidis (Hymenoptera: Bethylidae) with a new report on Anigraea albomaculata (Lepidoptera: Noctuidae) as an alternate host. Entomon 21:281-282

Risch SJ, Altieri M, Andow D (1983) Agroecosystem diversity and pest control: data, tentative conclusions, and new research directions. Environ Entomol 12:625-629

Rocca M, Greco NM (2015) Structure of the Tortricid-parasitoid community in a recently introduced crop. Neotrop Entomol 44:553-3559

Sadakathulla S, Md Jalaluddin S, Mohan R, Rajendran R, Velusamy $\mathrm{R}$ (1999) Coconut black-headed caterpillar menace in talipot palm. Indian Farming 49(3): 15

Saeed R, Razaq M, Hardy ICW (2015) The importance of alternative host plants as reservoirs of the cotton leaf hopper, Amrasca devastans, and its natural enemies. J Pest Sci 88:517-531

Sasidharan N (2011) Flowering plants of Kerala ver. 2.0 (DVD). Kerala Forest Research Institute, Peechi, Kerala, India. http:// www.keralaplants.in/search-flowering-plants-of-kerala.aspx

Sathiamma B, George MV, Kurian C (1973) Seasonal variation in the larval population of Nephantis serinopa Meyrick in the field as correlated with meteorological factors. J Plant Crops 1:161-163

Sathiamma B, Pillai GB, Abraham J, Bhat SK, Jayapal SP, Nair KR (1987) Norms for release of larval, prepupal and pupal parasitoids of Opisina arenosella Wlk. the leaf eating caterpillar of the coconut palm. J Plant Crops 15:118-122

Sathiamma B, Sabu AS, Pillai GB (1996) Field evaluation of the promising species of indigenous parasitoids in the biological suppression of Opisina arenosella Walker, the coconut leaf eating caterpillar. J Plant Crops 24:9-15

Schuman MS, van Dam NM, Beran F, Harpole WS (2016) How does plant chemical diversity contribute to biodiversity at higher trophic levels? Current Opin Insect Sci 14:46-55

Settle WH, Ariawan H, Astuti ET, Cahyana W, Hakim AL, Hindayana D, Lestari AS, Sartanto P (1996) Managing tropical rice pests through conservation of generalist natural enemies and alternative prey. Ecology 77:1975-1988

Shameer KS, Mohan C (2002) New host records of Brachymeria nosatoi Habu, the pupal parasitoid of Opisina arenosella Walk. Insect Environ 8:52-55

Sharma G (2011) Studies on lepidopterous insects associated with vegetables in Aravali Range, Rajasthan, India. Biol Forum 3:21-26

Shorthouse DP (2010) SimpleMappr, an online tool to produce publication-quality point maps. Available from http://www. simplemappr.net. Accessed 31 May 2017

Siegel S, Castellan NJ (1988) Nonparametric statistics for the behavioral sciences, 2nd edn. McGraw-Hill, New York
Singh SP, Rethinam P (2006) Introduction to the coconut leaf eating caterpillar Opisina arenosella Walker. CORD (Special Issue) 22:1-24

Sithanantham S, Chandish RB, Jalali SK, Bakthavatsalam N (ed) (2013) Biological control of insect pests using egg parasitoids, Springer India, p 424. Doi:10.1007/978-81-322-1181-5

Snart CJP, Hardy ICW, Barrett DA (2015) Entometabolomics: applications of modern analytical techniques to insect studies. Entomol Exp Appl 155:1-17

Stanton ML (1983) Spatial patterns in the plant community and their effect upon insect search. In: Ahmad S (ed) Herbivorous insects: host seeking behavior and mechanisms. Academic Press, New York, pp 125-155

Streito JC, Nibouche S (1997) First observations on the parasitoids associated with lepidopterous pests of cotton in Burkina Faso. Entomophaga 42:543-557

Sunderland KD, Powell W, Symondson WOC (2005) Populations and communities. In: Jervis MA (ed) Insects as natural enemies: a practical perspective. Springer, Dordrecht, pp 299-524

Talati GM, Butani PG (1988) A new host record for Nephantis serinopa Meyrick, the black headed caterpillar of coconut. Bull Entomol 29:142

Talati GM, Kapadia MN (1984) Influence of host plants on larval development, longevity and fecundity of Nephantis serinopa Meyrick (Lepidoptera: Cryptophasidae). Gujarat Agric Univ Res J 9:57-59

The Plant List (2013) Version 1.1. Published on the Internet; http:// www.theplantlist.org/. Accessed 15 Nov 2015

Thomas GV (2013) Coconut research and breeding in India. Talk delivered on 31st October 2013, Thailand. www.cpcri.nic.in

Valladares GR, Salvo A (1999) Insect-plant food webs could provide new clues for pest management. Environ Entomol 28:539-544

van Veen FJF, Memmott J, Godfray HCJ (2006a) Indirect effects, apparent competition and biological control. In: Brodeur J, Boivin G (eds) Trophic and guild interactions in biological control. Springer, Dordrecht, pp 145-169

van Veen FJF, Morris RJ, Godfray HCJ (2006b) Apparent competition, quantitative food webs, and the structure of phytophagous insect communities. Annu Rev Entomol 51:1-689

van Veen FJF, Müller CB, Pell JK, Godfray HCJ (2008) Food web structure of three guilds of natural enemies: predators, parasitoids and pathogens of aphids. J Anim Ecol 77:191-200

Varghese PT, Nair PKR, Nelliat EV, Varma R, Gopalasundaram P (1978) Intercropping with tuber crops in coconut gardens. In: Proceedings 1st plantation crops symposium (PLACROSYM), pp 399-415

Watt KEF (1965) Community stability and the strategy of biological control. Can Entomol 97:887-895

Wilson HB, Hassell MP, Godfray HCJ (1996) Host-parasitoid food webs: dynamics, persistence, and invasion. Am Nat 148:787-806

Yu DS, van Achterberg C, Hortsmann K (2012) Home of Ichneumonoidea. Available from: http://www.taxapad.com. Accessed 8 Nov 2015

Zhang Z, Zhou Z, Xu Y, Huang X, Zhang L, Mu W (2017) Effects of intercropping tea with aromatic plants on population dynamics of arthropods in Chinese tea plantations. J Pest Sci 90:227-237 